Looking to the future, it may be said that unless the existing degree of lawlessness in the south can be stamped out, wild life will suffer, and the more vulnerable and commercially valuable creatures may disappear altogether.

\title{
THE GOLD COAST
}

\section{REPORT ON THE GAME DEPARTMENT FOR THE YEAR 1950-51}

The Game Department came into being on the 1st April, 1950. Throughout the year work was confined to the Northern Territories of the Gold Coast.

\section{Part I-Game Reserves}

Proposed Black Volta Reserve.

2. Selection of an area of approximately 600 square miles in Western Gonja was completed. The Selection Report, submitted to His Honour the Chief Commissioner, was discussed by the Central Land Planning Committee at Tamale and approved. The Chief Commissioner recommended to the Ministry of Agriculture and Natural Resources that the proposed reserve be constituted under section 2 (13) of Cap. 203 of the Laws. Consideration of the proposal by the Ministry was delayed because the area impinged upon an area in respect of which a private individual was seeking an exclusive prospecting licence. This application was subsequently withdrawn but the necessary regulation could not be made by the end of the year.

The Kulparon River Valley.

3. The valley of the River Kulpawn, in Wa District, appeared to be a suitable area for a Game Reserve, but after discussion with the Department of Tsetse Control it was found that a recommendation for resettlement of this area had been made. The project of examining the area of the valley was accordingly abandoned.

\section{Proposed Sisili Game Reserve.}

4. The area of the Sisili Valley, to the north of the TumuNavrongo Road, was examined and was considered suitable as a Game Reserve. The stock of game is better than that in the proposed Black Volta Reserve and includes at least one species, 
the comparatively rare Senegal hartebeest (Damaliscus korrigum), not previously known to exist there. This area of approximately 120 square miles is practically uninhabited, and owing to the incidence of disease in the valley of the upper Sisili, it appears that it is unlikely to be capable of development. A Selection Report on the area was submitted to the Chief Commissioner in February, 1951.

\section{Elephant.}

\section{Part II-Game Control}

5. Damage was done by elephants to crops in the Wa District, but on the few occasions when it was possible to visit the area affected the animals were not met.

\section{Lion.}

6. No reports of attacks by lions on man or livestock were received. The two lions which killed cattle in the immediate vicinity of Lawra in the previous year did not return in the year under review.

\section{Hippopotamus.}

7. One hippopotamus reported to be attacking canoes in the River Black Volta was shot.

\section{Crocodile.}

8. A census of cattle killed by crocodiles in the Black Volta River, taken by the Chief of Lawra, revealed that 150 were taken in the 1949-50 dry season. In addition, very large numbers of goats and sheep were lost. No human beings were reported as having been taken in that period but certain crocodiles were known to be man-eaters and to have been responsible for several deaths in previous years. The months of February and March were mainly devoted to the marking down and destroying of crocodiles with bad records. Twenty-three were killed by the end of the year, the largest a male of $14 \mathrm{ft} .1 \mathrm{in}$., the general average being 10 to 11 feet. The stretch of river dealt with was practically clear by the end of the year.

\section{Part III-Legislation}

9. A Report on the Use of Spring Traps (Gins) was submitted. These traps of the larger sizes are estimated to be the biggest factor in the destruction of game in the southern part of the Gold Coast, and their use is rapidly spreading to the north. In 
addition to being destructive of game the larger traps are a menace to man and his livestock. Legislation prohibiting the possession and use of the larger and more dangerous traps was under consideration at the end of the year.

10. Recommendations for a comprehensive revision of the Wild Animals Preservation Ordinance, Cap. 203, were submitted for consideration.

\section{Part IV-Staff}

11. The Game Warden, the only established officer in the department, was in charge throughout the year.

12. The training of Game Scouts for control purposes was hampered at the beginning of the year by lack of rifles and ammunition. Three $\cdot 404$ rifles and $\mathbf{1 , 5 0 0}$ rounds of ammunition were received in the middle of July, but only one man of the six required for Game Control was passed as being fully trained by the end of the year.

13. No permanent labour force was employed : casual labour was used on the inspection of areas selected as Game Reserves.

14. Total expenditure by the department during the year was $£ 2,222$.

\section{A CRITICISM}

By G. S. Cansdale

\section{Part I-Game Reserves}

To those unaware of the position in the Gold Coast the first reaction to the above report is probably one of satisfaction that a game department has at last been established and that work has started, but a careful examination of the report raises a number of doubts as to the value of the work that has been done. It is perhaps worth while commenting on the Report in the light of personal knowledge, and after detailed discussion with other officers interested in game, who know the areas concerned.

The Proposed Black Volta Reserve.-No mention is made of the game found in this area and one wonders to what extent the area was actually traversed and whether any detailed work was done on its fauna and ecology. Nothing is said about the objects for which this reserve is to be made.

The Proposed Sisili Game Reserve.-It is a little misleading to speak of the comparatively rare Senegal hartebeest (Damaliscus korrigum) ; this is very common north of the Gold Coast and the area in question is, in fact, on the very southern edge of 